\title{
Morphology, Histology and Histochemistry of the Venom Apparatus of the Centipede, Scolopendra valida (Chilopoda, Scolopendridae)
}

\author{
Morfología, Histología e Histoquímica del Aparato Venenoso del Ciempiés, \\ Scolopendra valida (Chilopoda, Scolopendridae)
}

Bashir M. Jarrar

JARRAR, B. M. Morphology, histology and histochemistry of the venom apparatus of the centipede, Scolopendra valida ( Chilopoda, Scolopendridae). Int. J. Morphol., 28(1):19-25, 2010.

SUMMARY: Morphological, histological and histochemical characterizations of the venom apparatus of the centapede, $S$. valida have been investigated. The venom apparatus of Scolopendra valida consists of a pair of maxillipedes and venom glands situated anteriorly in the prosoma on either side of the first segment of the body. Each venom gland is continuous with a hollow tubular claw possessing a sharp tip and subterminal pore located on the outer curvature. The glandular epithelium is folded and consists of a mass of secretory epithelium, covered by a sheath of striated muscles. The secretory epithelium consists of high columnar venom-producing cells having dense cytoplasmic venom granules. The glandular canal lacks musculature and is lined with chitinous internal layer and simple cuboidal epithelium. The histochemical results indicate that the venom-producing cells of both glands elaborate glycosaminoglycan, acid mucosubstances, certain amino acids and proteins, but are devoid of glycogen. The structure and secretions of centipede venom glands are discussed within the context of the present results.

KEY WORDS: Scolopendra valida; Venom apparatus; Microanatomy; Centapede; Saudi Arabia.

\section{INTRODUCTION}

Centipedes are distributed widely, especially in warm, temperate and tropical region (Norris, 1999; Lewis, 1981, 1996). Of 3000 species of centipedes have been identified, 620 species were identified of medical importance and dangerous species belong to the genus Scolopedra (Norris; Stewart, 1997). Nine species of centipedes were recorded and described in Saudi Arabia, of which five species of Scolopendridae have been reported to be present in various localities in Saudi Arabia (Lewis, 1986; Lewis \& Wrinik, 1990). Scolopendra valida is the largest centipede in Saudi Arabia and it is distinguished from other species by the ring suture on the first tergite (Lewis, 1986).

Centipede stings occur in the warmer climates throughout the world and their painful results have been known for centuries. The centipede venom is toxic to both mammals and insects (Menez et al., 1990). The bites of centipedes have been reported to cause constitutional and systemic symptoms including: severe pain, local pruritus, headache, nausea, vomiting, anxiety, palpitation, local tissue swelling, erythema, necrosis, lymph node swelling, ischemia and rhabdomyolysis (Bush et al., 2001; Ozsarac et al., 2001; Serinken et al., 2005; Yildiz et al., 2006; Vazirianzadeh et al., 2007). Nearly about five thousands centipede bites are reported every year in Turkey (Serinken et al.) and documented reports regarding Scolopendra valida biting appeared recently from Iran (Vazirianzadeh et al.), with no reports regarding centipede biting in Saudi Arabia. According to Lewis (1986), death from centipedes bites are extremely rare and the reports of fatalities should be treated with caution. However, a seven year old girl in the Philipines died after being bitten by Scolopendra subspinipes (Remington, 1950; Norris), while no fatality due to centipede stings has been reported in Saudi Arabia. The largest species 
are known to kill small vertebrates including some birds, reptiles and mammals.

Few studies have focused on the biochemistry of the centipede venom (Welsh \& Batty, 1963; Mohamed et al., 1980, 1983; Gomes et al., 1982a, 1982b; Logan \& Ogden, 1985; Malta et al., 2008), while the histochemical work, if any is very limited. With this objective, the present study was performed to characterize the histology and histochemistry of the venom glands of the centipede Scolopendra valida.

\section{MATERIAL AND METHOD}

The venom apparatus of 10 adult Scolopendra vali$d a$ captured from Al-Jouf provinces of Saudi Arabia, were utilized. The telson was removed from each and quickly immersed for 3 days in one of the following fixatives: $10 \%$ neutral buffered formalin ( $\mathrm{pH} 7.4$ ) with $2 \%$ calcium acetate, Bouin's fluid and Gendre's fluid. The fixed samples then thoroughly washed in running water, dehydrated, cleared, impregnated and embedded in paraffin wax, sectioned at 4$5 \mu \mathrm{m}$ thickness and stained with haematoxylin-eosin and Masson trichrome stains for histological examination. Paraffin sections were then utilized in the following histochemical reactions to detect mucosubstances, proteins and amino acids:

Neutral mucosubstances. Periodic acid-Schiff (PAS) technique, and Best's carmine (Pearse, 1985).

Acid mucosubstances. Alcian blue (AB) at $\mathrm{pH} 2.5$ and 1.0 (Drury \& Wallington, 1983).

Distinction between acidic and neutral mucosubstances. $\mathrm{AB}(\mathrm{pH} 2.5)-\mathrm{PAS}$ and $\mathrm{AB}(\mathrm{pH} 1.0)-\mathrm{PAS}$ (Pearse).

Distinction between sulfomucins and sialomucins. Aldehyde fuchsin (AF) and aldehyde fuchsin - alcian blue at $\mathrm{pH} 2.5$, strong $\left(60^{\circ} \mathrm{C}, 4 \mathrm{hr}\right)$ methylation-saponification$\mathrm{AB}, \mathrm{pH} 2.5$; acid hydrolysis $\left(0.1 \mathrm{~N} \mathrm{HCl}, 60^{\circ} \mathrm{C}, 4 \mathrm{hr}\right)-\mathrm{AB}(\mathrm{pH}$ 2.5 ); toluidine blue (TB) buffered at $\mathrm{pH} 1.7 \& 3.4$ and critical electrolyte concentration (CEC) technique for extinction of alcianophilia at $\mathrm{pH} 5.6$ in the presence of gradual concentration of $\mathrm{Mg}^{++}$(Pearse). In the combined aldehyde fuchsin-alcian blue sequential techniques, sulfomucins stain purple blue and sialomucins blue (Bancroft \& Gamble, 2002; Kiernan, 1989). Methylation blocks subsequential stainig of simple mucosubstances by esterification of carboxyl groups and complex sulfated mucosubstances desulphation. Subsequent treatment with potassium hydroxide (saponification) after methylation will restore the staining of carboxyl groups (Drury \& Wallington). The mucosubstances that are stained at $0.1 \mathrm{M} \mathrm{MgCl}$ in the CEC reaction, but not at $0.2 \mathrm{M} \mathrm{MgCl}_{2}$ are believed to contain carboxyl group and no sulfate groups. Sulfated mucosubstances, on the other hand, stain strongly and selectively at $0.2 \mathrm{M} \mathrm{Mg}^{++}$but lose their alcianophilia at different levels with increasing $\mathrm{MgCl}_{2}$ concentration (Pearse).

Enzymes digestion tests. Diastase-PAS technique; neuraminidase (Sialidase, Vibrio cholerae, type V)-AB at $\mathrm{pH}$ 2.5; hyaluronidase (testicular)-AB $\mathrm{pH}$ 2.5, neuraminidase-TB (pH 3.7) and hyaluronidase- $\mathrm{TB}$ pH 2.0 (Pearse). Control sections were incubated in the buffer solutions without the enzymes. Sialomucins can be identified by alcianophilia at $\mathrm{pH} 2.5$, which is partially lost following acid hydrolysis and completely removed after neuraminidase digestion, but does not affect the staining of sulfated mucosubstances. A loss of alcianophilia after hyaluronidase digestion is due to the removal of hyaluronic acid and chondroitin sulfates.

Proteins. Mercuric bromophenol blue and ninhydrin-Schiff methods were used for detection of proteins (Pearse).

Amino acids. The following tests were utilized: The pDMAB-nitrate method for tryptophan; the Sakaguchi dichloronaphthol reaction for arginine; the Millon's reaction (Baker modification) for tyrosine and the ferric ferrocyanide method for cystein (Pearse).

\section{RESULTS}

Morphology and histology. The venom apparatus of Scolopendra valida consists of a modified pair of front legs on either side of the body just behind the head. It is situated anteriorly in the prosoma and it is composed of a pair of maxillipedes and venom glands. The venom glands are of equal size and found inside a chitinous body wall at the basal of the maxillipeds of the first segment behind the head. Each venom gland is covered by an external layer of striated muscle lined internally and externally by elastic-rich basal membrane. Each gland has its own duct ends at the venom subterminal pore located on the outer curvature of the claw. The toxicoganths of Scolopendra valida are hollow tubes with sharp tips.

The glandular epithelium is folded and consists of a mass of secretory epithelium, covered by a sheath of striated muscles and chitinous envelope (Figs. 1 and 2). The glan- 
dular epithelium consists of venom-producing cells and nonsecretory supporting cells (Fig. 3). The venom producing cells are high columnar in shape, of apocrine type and filled with coarse granules in their apical portion with small nuclei situated at their bases. The supporting cells are subcuboidal in shape, located between the venom-producing cells and the underlying basement membrane.

The common canal of the venom apparatus of Scolopendra valida lacks musculature and is lined with nonexcretory simple cuboidal epithelium followed by chitinous external layer (Fig. 4). The extruded venom, within the lumen of the gland, and within the apical cytoplasm of the venom producing cells, contains fine and coarse granules, with discrete morphologies, that showed variable coloration pattern with the same histological stain.

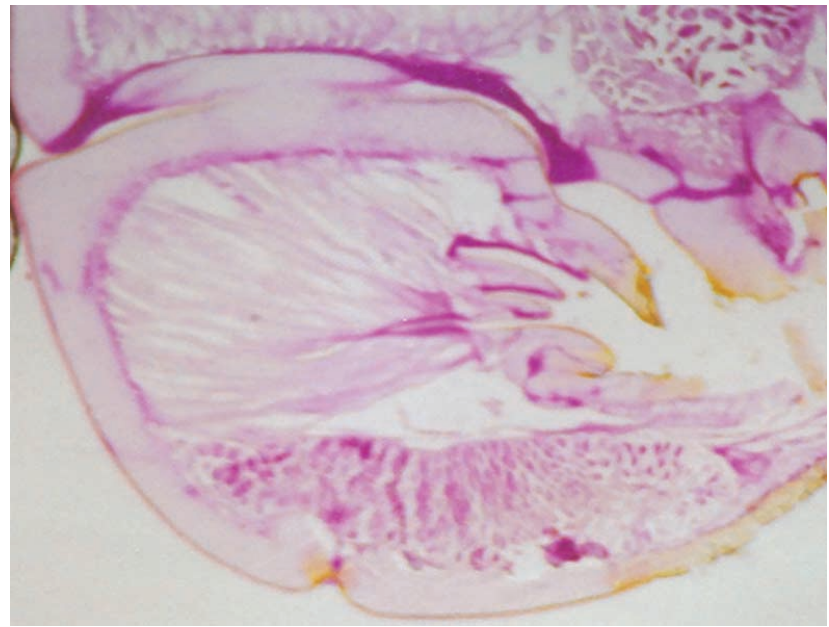

Fig. 1. Sections through the venom glands of Scolopendra valida. The secretory epithelium together with the glandular muscle sheath surrounded by chitinous envelope.

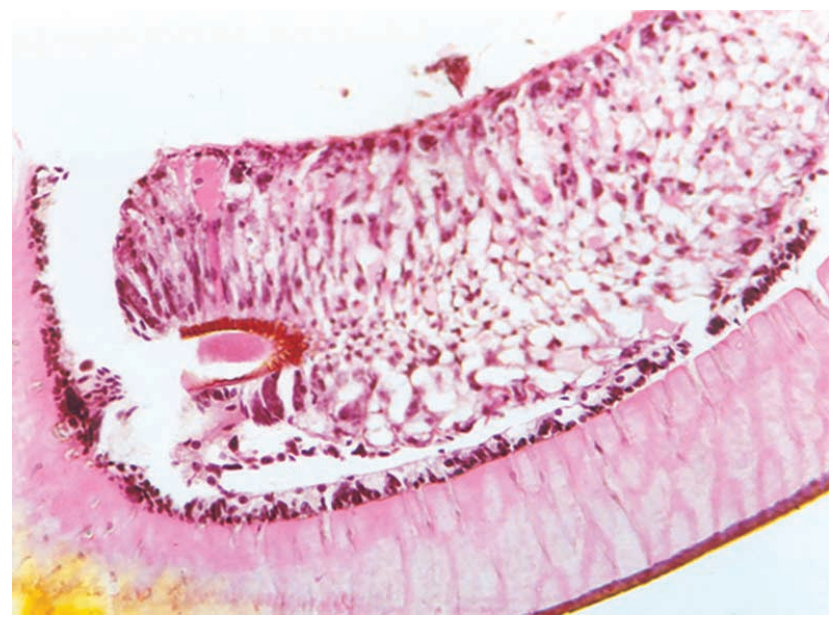

Fig. 2. Sections through the venom glands of Scolopendra valida. The secretory epithelium covered by chitinous envelope. H\&E

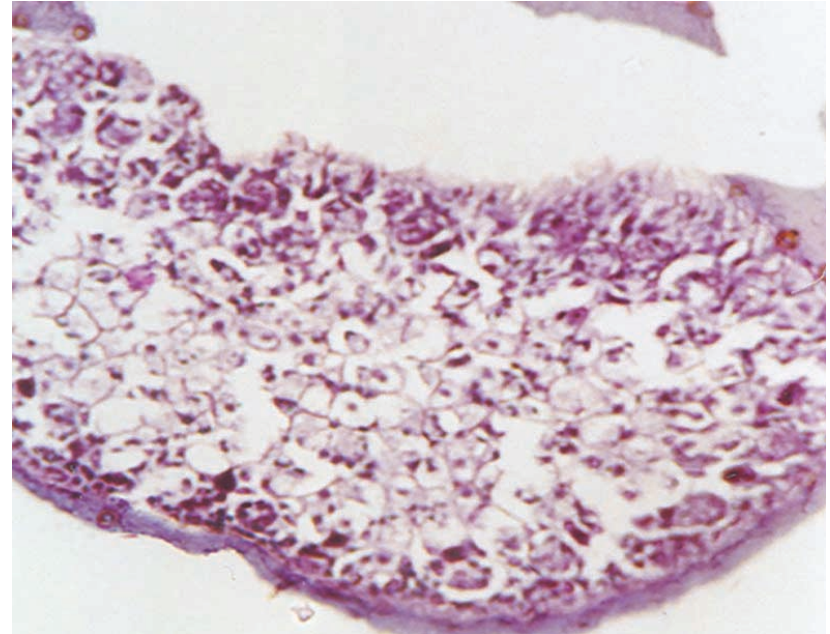

Fig. 3. Sections through the venom glands of Scolopendra vali$d a$. The secretory epithelium showing the venom producing cells. $\mathrm{H} \& \mathrm{E}$

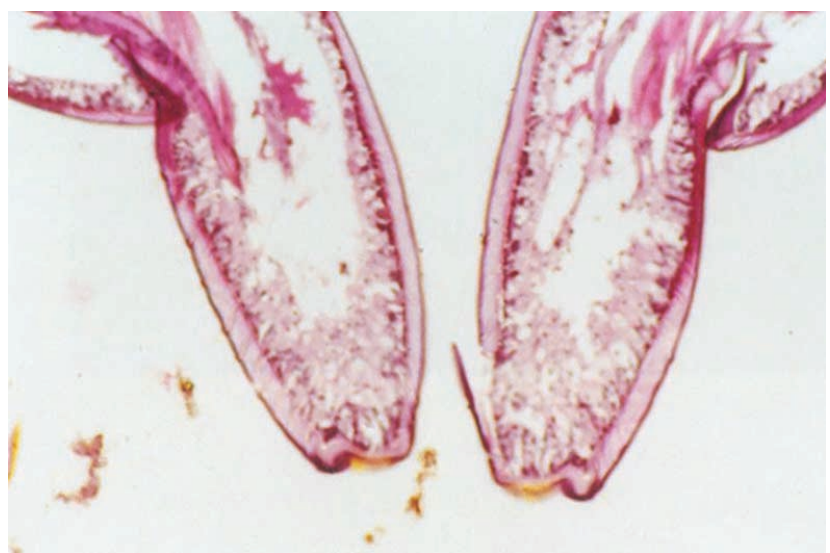

Fig. 4. Sections through the venom glands of Scolopendra valida. Longitudinal sections in the toxicoganths. H\&E

Carbohydrates histochemistry. The venom-producing cells reacted positively with PAS reaction, but responded negatively to Best's carmine stain (Fig.5). This reactivity withstood a- amylase digestion, but was completely blocked by both phenyl hydrazine and acetylation, and partly restored by deacetylation-PAS sequential techniques. These cells showed alcianophilia at both $\mathrm{pH} 2.5$ (Fig. 6) and 1.0, which was not affected by neuraminidase or hyaluronidase digestion, partly blocked by acid hydrolysis, completely blocked by strong methylation, and restored partially with methylation-saponification sequential techniques. The glandular epithelium showed positive reaction with the CEC at $0.2 \mathrm{M}$ and a feeble one at $0.3 \mathrm{M} \mathrm{Mg}^{++}$. The venom glands showed weak metachromatic reaction with $\mathrm{TB}$ at both $\mathrm{pH}$ 1.7 and 3.4. 


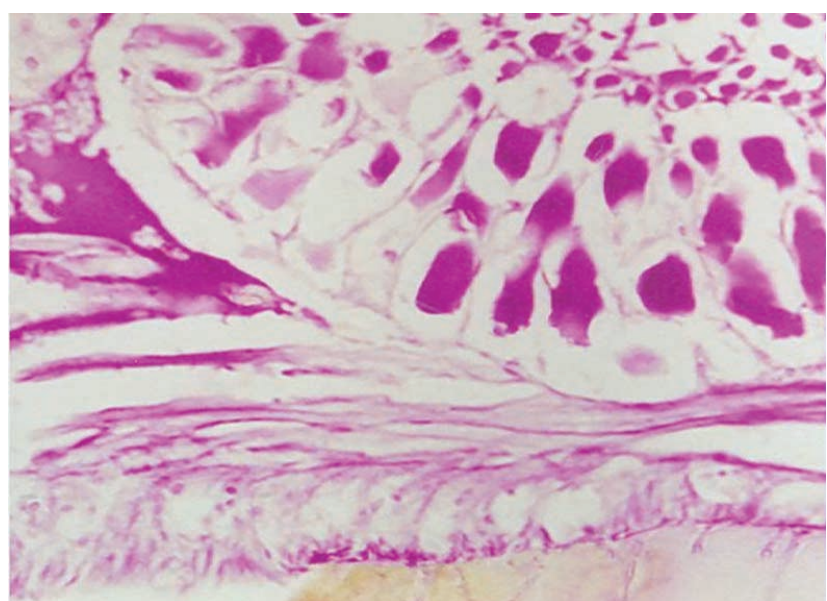

Fig. 5. Sections through the venom glands of Scolopendra valida. The glandular epithelium stained periodic acid-Schiff stain.

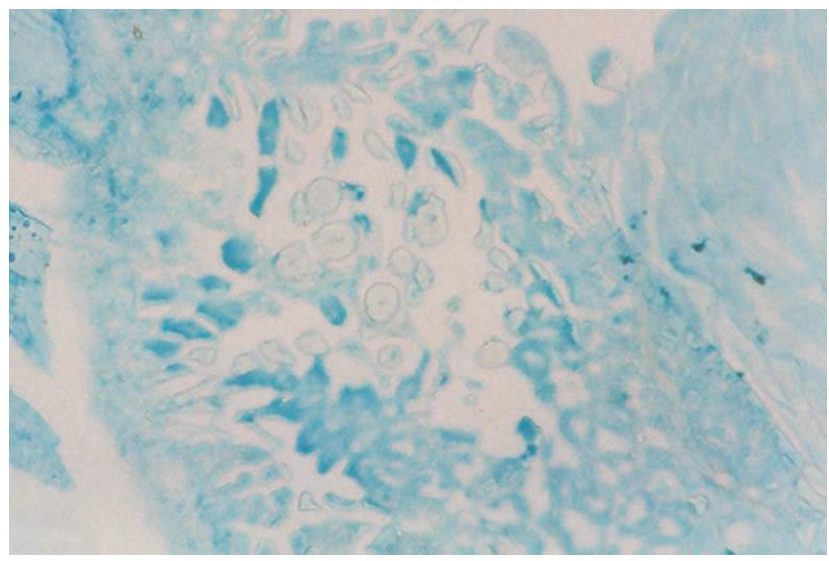

Fig. 6. Sections through the venom glands of Scolopendra valida. The glandular epithelium stained with alcian blue $(\mathrm{pH} 2.5)$ stain.

Protein histochemistry. The venom-producing cells reacted positively to ninhydrin-Sciff and mercuric bromophenol blue techniques (Figs. 7 and 8).

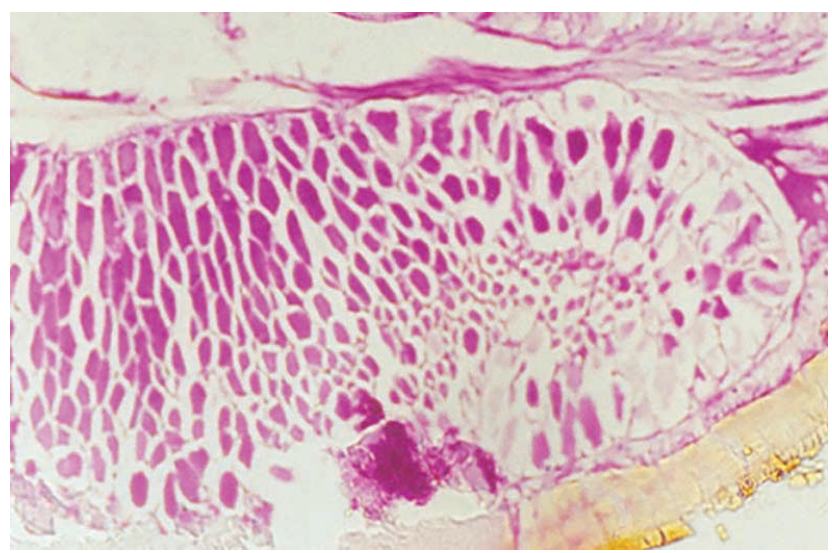

Fig. 7. Sections through the venom glands of Scolopendra valida. The glandular epithelium stained with ninhydrin-Schiff stain for proteins.

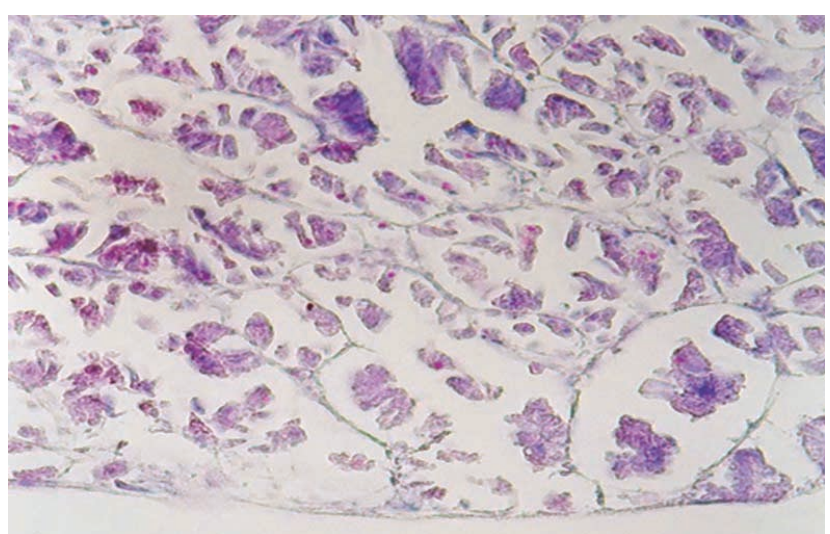

Fig. 8. Sections through the venom glands of Scolopendra valida. The glandular epithelium stained with mercuric bromophenol blue for proteins.

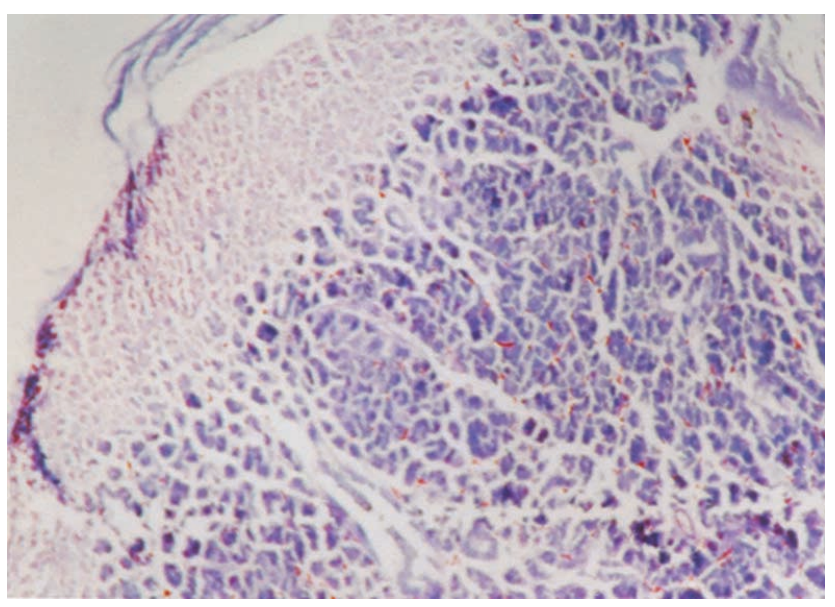

Fig. 9. Sections through the venom glands of Scolopendra valida. The glandular epithelium stained with the p-DMAB-nitrate method for tryptophan.

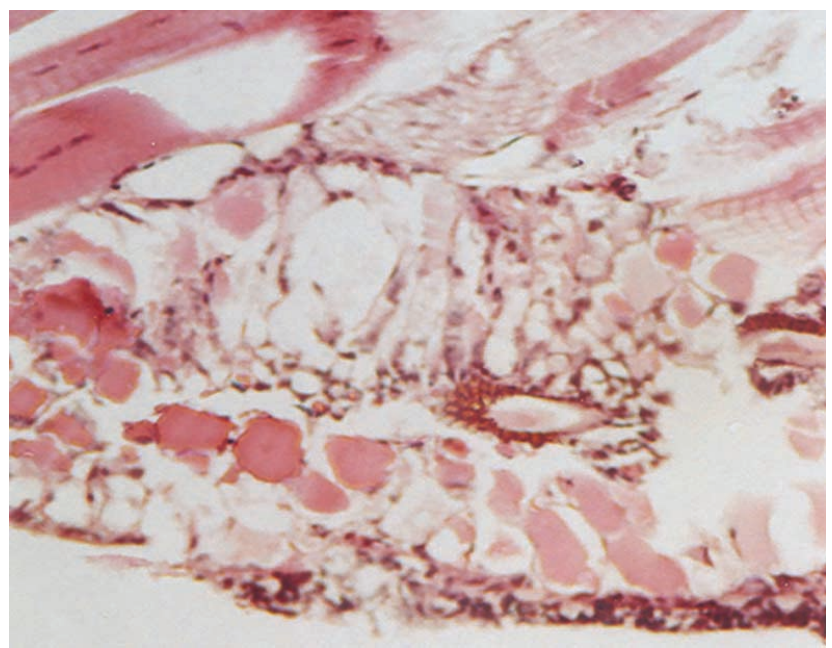

Fig. 10. Sections through the venom glands of Scolopendra vali$d a$. The glandular epithelium stained with the Sakaguchi dichloronaphthol reaction for arginine. 
Amino acid histochemistry. Positive histochemical reactions for tyrosine, tryptophan and arginine and to lesser

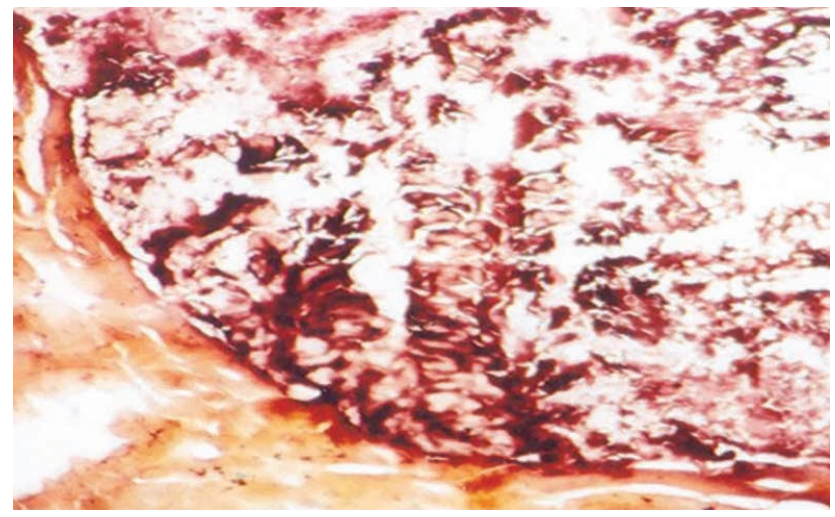

Fig. 11. Sections through the venom glands of Scolopendra vali$d a$. The glandular epithelium stained with the Millon's reaction for tyrosine.

\section{DISCUSSION}

The centipede venom is toxic to both vertebrates and invertebrates and the largest species are known to kill small vertebrates including some birds, reptiles and mammals (Menez et al.). Scolopendra valida stings were recorded to cause haemoglobinuria and haematuria in addition to erythema, itching and irritation (Vazirianzadeh et al.). The structure of the venom gland of Scolopendra valida with its histochemical components as seen by the results of the present study together with its mechanical support specially the venom claw provide a well adaptive functioning venombearing tool to immobilize prey or defend against predators.

A tentative interpretation of the type of mucosubstances secreted by the venom gland of Scolopendra valida could be made depending on the present results along with classification basis of mucosubstances proposed by histochemists (Pearse; Bancroft \& Gamble; Gabe \& SaintGirons, 1969; Kiernan). Neutral mucosubstances are PAS positive, diastase resistant, as well as unstainable by cationic dyes. Acetylation produces derivatives of primary and secondary amines which prevent 1, 2 glycol groups, from reacting with PAS indicating the presence of neutral mucosubstances (Pearse). The venom-producing cells of Scolopendra valida in the present study were found to be PAS positive and diastase resistant, which indicate that the venom of the scorpion species under study to contain neutral mucosubstances but devoid of glycogen. The nature of neutral mucosubstances as a polymer of glucoseamine might indicate a possible role in osmoregulation and the transfer of the protein fragment of the venom in the tissue of the extent for cystein were seen in both venom producing cells and in the luminal released venom granules (Figs. 9-12).

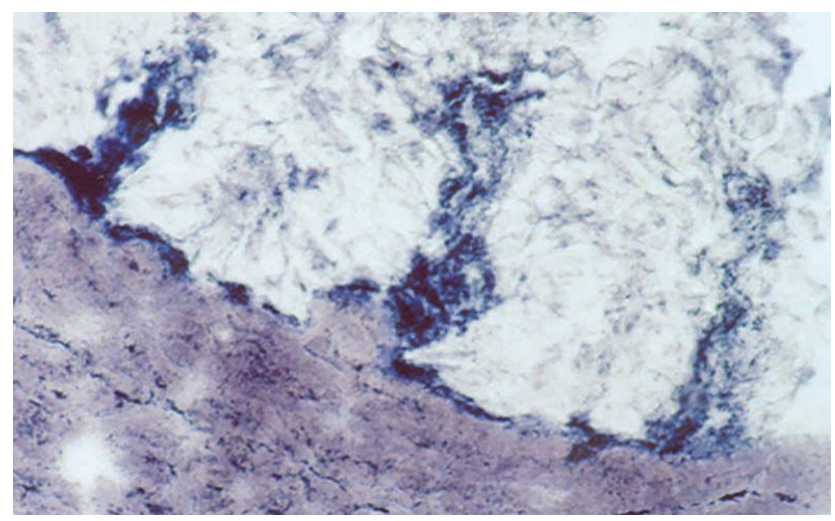

Fig. 12. Sections through the venom glands of Scolopendra vali$d a$. The glandular epithelium stained with the ferric ferrocyanide method for cysteine. victim. Neutral mucosubstances have been found in the venom of the most dangerous scorpions (Taib \& Jarrar, 1993; Jarrar \& Al-Rowaily, 2008).

On the other hand, these glands of Scolopendra vali$d a$ were positive to alcian blue and the aldehyde fuchsin techniques and thus considered as glands that secrete acid mucosubstances. Alcian blue is generally considered as being specific for identifying acid mucosubstances where alcianophilia at $\mathrm{pH} 2.5$ and 1.0 is specific for sialomucins and sulformucins, respectively (Pearse). The results of the histochemical techniques indicated that venom of Scolopendra contains sialidase-liable sialomucins and hyaluronidase-resistant sulphomucins. Acid mucosubstances in the venom of Scolopendra valida as seen in the results of the present work might indicate a role in speeding up of the venom absorption upon injection in the victim.

The histochemical results of the present investigation indicate the presence of cysteine, arginine, tyrosine and tryptophan in Scolopendra valida venom. Cysteine may provide sulfhydryl groups that can interact to stabilize the venom fractions, while the venom content of arginine indicates the basic nature of protein fraction of the venom. It is believed that basic proteins are responsible for the venom neurotoxic activities that may play a role in blocking sodium channels of the excitable cell membranes (Catterall, 1976; Fontecilla-Camps et al., 1980). Tryptophan in the venom is believed to contribute in the binding of the toxin with the neuronal membranes of the victim (Hassani et al., 1999). 
JARRAR, B. M. Morfología, histología e histoquímica del aparato venenoso del ciempiés, Scolopendra valida ( Chilopoda, Scolopendridae). Int. J. Morphol., 28(1):19-25, 2010.

RESUMEN: Fueron investigadas las características morfológicas, histológicas e histoquímicas del aparato venenoso del ciempiés, $S$. valida. El aparato venenoso de Scolopendra valida consta de un par de maxilopodos y glándulas de veneno situadas anteriormente en el prosoma, a cada lado del primer segmento del cuerpo. Cada glándula de veneno se continúa en una garra con una cavidad tubular que posee una punta afilada y un poro subterminal situado sobre la curvatura externa. El epitelio glandular es plegado y se compone de una masa de epitelio secretor, cubierto por una vaina de los músculos estriados. El epitelio secretor consiste en células columnares altas productoras de veneno con gránulos citoplasmáticos de veneno densos. El conducto glandular carece de musculatura y está revestido por capa interna quitinosa y epitelio cuboidal simple. Los resultados histoquímicos indican que las células productoras de veneno de ambas glándulas elaboran glucosaminoglucanos mucosustancias ácidas, ciertos aminoácidos y proteínas, pero carecen de glucógeno. La estructura y las secreciones de las glándulas de veneno del ciempiés son examinadas en el contexto de los presentes resultados.

PALABRAS CLAVE: Scolopendra valida; Aparato de veneno; Microanatomía; Centípedo; Arabia Saudita.

\section{REFERENCES}

Bancroft, J. D. \& Gamble, M. Theory and practice of histological techniques. $5^{\text {th }}$ ed. London, Churchill Livingstone, 2002.

Bush S. P.; King, B. O.; Norris R. L. \& Stockwell S. A. Centipede envenomation. Wilderness Environ. Med., 12(2):93-9, 2001.

Catterall, W. A. Purification of a toxic protein from scorpion venom which activates the action potential $\mathrm{Na}^{+}$ionphore. J. Biol. Chem., 251(18):5528-36, 1976.

Drury, R. A. \& Wallington, B. Carleton's histological techniques. $5^{\text {th }}$ Ed. New York, Oxford University Press, 1983.

Fontecilla-Camps, J. C.; Almassy, R. J.; Suddath, F. L.; Watt, D. D. \& Bugg, C. E. Three-dimentional structure of a protein from Scorpion venom: A new structural class of neurotoxins. Proc. Natl. Acad. Sci. U S A., 11:6496-500, 1980 .

Gabe, M. \& Saint-Girons, H. Donnees histologiques sur les glands salivaires des lepidosauriens. Mus. Natl. Hist. Nat., 58:1-112, 1969.

Gomes, A.; Datta, A.; Sarangi, B.; Kar, P. K. \& Lahiri, S. C. Occurrence of histamine and histamine release by centipede venom. Indian J. Med. Sci., 76:888, 1982a.

Gomes, A.; Datta, A.; Sarangi, B.; Kar, P. K. \& Lahiri, S. C. Pharmacodynamics of venom of the centipede Scolopendra subspinipes dehaani Brandt. Indian J. Exp. Biol., 2(20):615-8, 1882b.
Hassani, O.; Mansuelle, P.; Cestele, S.; Bourdeaux, M.; Rochat, H. \& Sampier, F. Role of lysine and tryptophan residues in the biological activity of toxin VII (Ts $g$ ) from the scorpion Tityus serrulatus. Eur. J. Biochem., 260:76-86, 1999.

Kiernan, J. H. Histological and histochemical methods. Theory and practice. $2^{\text {nd }}$ Ed. Oxford, Pergamon Press, 1989.

Jarrar, B. M. \& Al-Rowaily, M. A. Histology and histochemistry of the venom apparatus of the black scorpion Androctonus crassicauda (Olivier, 1807) (Scorpiones: Buthidae). J. Venom. Anim. Toxins Incl. Trop. Dis., 14(3):514-26, 2008.

Lewis, J. E. Centipedes of Saudi Arabia. Fauna Saudi Arabia, 8:20-30, 1986.

Lewis, J. E. Further records of scolopendromorph and geophilomorph centipedes from the Arabian peninsula with a note by Dr. E. H. Eason on Lithobius erythrocephalus cronebergii Seliwanoff. Fauna Saudi Arabia, 15:137-156, 1996.

Lewis, J. E. The Biology of Centipedes. Cambridge, Cambridge University Press, 1981. pp.476.

Lewis, J. E. \& Wrinik, W. On the centipedes of Yemen. Zool. Middle East, 4:61-70, 1990.

Logan, J. L. \& Ogden, D. A. Rhabdomyolysis and acute renal failure following the bite of the giant desert centipede Scolopendra heros. West J. Med., 142:549-50, 1985. 
Malta, M. B.; Lira, M. S.; Soares, S. L.; Rocha, G. C.; Knysak, I.; Martinus, R.; Guizze, S. P.; Santoro, M. L. \& Barbaro, K. C. Toxic activities of Brazilian centipede venoms. Toxicon, 52(2):255-63, 2008.

Menez, A.; Zimmerman, K.; Zimmerman, S. \& Heatwole, H. Venom apparatus and toxicity of the centipede Ethostigmus rupides (Chilopod, Scolopendridae). J. Morphol., 206:303-12, 1990.

Mohamed, A. H.; Abu-Sinna, G.; El-Shabaka, H. A. \& ElAal, A. A. Effects of an extract from the centipede Scolopendra morsitans on intestine, uterus, and heart contractions and on blood glucose and liver and muscle glycogen levels. Toxicon, 18:581-9, 1980.

Mohamed, A. H.; Abu-Sinna, G.; El-Shabaka, H. A. \& ElAal, A. A. Proteins, lipids, lipoproteins, and some enzyme characterizations of the venom extract from the centipede Scolopendra morsitans. Toxicon, 21:371-7, 1983.

Norris, R. L. Centipede envenomations. In: Adler, J. N.; Brenner, B.; Droner, S. (Eds). Medicine: Emergency Medicine. Boston, Boston e Medicine Corporation, 1999.

Ozsarac, M.; Karcioglu, O.; Ayrik, C.; Somuncu, F. \& Gumrukcu, S. Acute coronary ischemia following centipede envenomation: Case report and review of literature. Wilderness Environ. Med., 15(2):109-12, 2001.

Pearse, A. G. Histochemistry. Theoretical and applied, analytical technology. $4^{\text {th }}$ Ed. New York, Churchill Livingstone, 1985.

Remington, C. L. The bite and habits of a giant centipede (Scolopendra subspinipes) in the Philippine Islands. Am. J. Trop. Med., 30:453-5, 1950.

Serinken, M.; Erdur, B.; Sener, S.; Kabay, B. \& Alper, C. A. A case of mortal necrotizing fasciitis of the Trunk resulting from a centipede (Scolopendra moritans) Bite. Internet J. Emergency Med., 2(2):1-8, 2005.

Stewart, J. W. Centipedes and millipedes. Texas Agricultural Extension Service. Texas, The Texas A \& M University System, 1997.

Taib, N. T. \& Jarrar, B. M. Histological and histochemical characterization of the venom apparatus of Palestine yellow scorpion, Leiurus quinquestriatus Hemprich \& Ehrenberg 1828. Trop. Zool., 6:143-52, 1993.
Vazirianzadeh, B.; Rahmanei, A. \& Moravvej, S. Two cases of chilopoda (centipede) biting from Alwaz, Iran. Pak. J. Med. Sci., 23(6):956-8, 2007.

Welsh, J. H. \& Batty, C. S. 5-Hydroxytryptamine content of some arthropod venoms and venom containing parts. Toxicon, 1:165, 1963.

Yildiz, A.; Biceroglu, S.; Yakut, N.; Bilir, S.; Akdemir, R. \& Akilli, A. Acute myocardial infarction in a young man caused by centipede sting. Emerg. Med. J., 23(30):10-1, 2006.

Correspondence to:

Bashir M. Jarrar

Dept. of Clinical Laboratory Sciences

College of Applied Medical Sciences

AL-Jouf University, P.O. Box (2014)

Skaka - Al-Jouf

Saudi Arabia

Tel: 00966-503229854

Fax: 00966-46257328

Email: bashirjarrar@yahoo.com

Received: 09-04-2009

Accepted: 22-01-2010 
